\title{
Linguistic Features of Persuasive Communication: The Case of DRTV Short Form Spots
}

\author{
ABSTRACT
}

Direct response television commercials (DRTV) exhibit a very specific style of speech and delivery whose main function is to boost the product's value and sales. This paper presents the findings of the structural and the linguistic analyses of three English DRTV short form spots as seen on Highstreet TV. The emphasis is on the verbal strategies used by advertisers to get the consumers' attention, develop their interest and desire to own the product and to convince them to purchase it. These strategies include different lexical, syntactic and prosodic features. The structural analysis focuses mainly on non-verbal strategies of broadcasting advertisements whose purpose is to inspire interest and credibility in potential consumers.

Keywords: direct response television (DRTV) short form spots; AIDA model; persuasive communication; lexical complexity; syntactic complexity; prosody; Coh-Metrix; VocabProfile

\section{Jezikovne značilnosti $v$ prepričevalnem sporazumevanju: Primer kratkih tv oglasnih sporočil z neposrednim odzivom}

\section{POVZETEK}

Za televizijske oglase z neposrednim odzivom je značilen poseben slog govorne izvedbe, katere glavna naloga je povečati vrednost in prodajo oglaševanim izdelkom. V tem članku so predstavljene ugotovitve strukturne in jezikovne analize treh angleških kratkih reklam z neposrednim odzivom, ki so bile predvajane na angleškem televizijskem kanalu Highstreet TV. Poudarek je na verbalnih strategijah, ki jih oglaševalci uporabljajo, da pridobijo pozornost potrošnikov, pri njih razvijejo zanimanje in željo imeti oglaševani izdelek in jih prepričajo, da ga tudi kupijo. Verbalne strategije zajemajo besedišče, skladnjo in intonacijo. Strukturna analiza pa se osredinja na neverbalne strategije televizijskega oglaševanja, katerih cilj je prebuditi zanimanje in zaupanje v oglaševani izdelek.

Ključne besede: kratki oglasi $\mathrm{z}$ neposrednim odzivom; model AIDA; prepričevalno sporazumevanje; leksikalna kompleksnost; skladenjska kompleksnost; prozodija; Coh-Metrix; VocabProfile 


\section{Linguistic Features of Persuasive Communication: The Case of DRTV Short Form Spots}

\section{Introduction}

Advertising is a big industry within which television advertisements represent only one form of marketing communication. Although producing a television commercial is costly and time consuming, it is also one of the most effective ways to introduce a product and to convince the audience to buy it. A special type of television advertising is commercials with a direct response, also known as commercials for on-line shopping or shopping from the armchair.

Direct response television (DRTV) commercials fall into two categories: infomercials and short form spots. The former are usually 30 or even 60 minutes long, whereas the latter are from 60 to 120 seconds in length. DRTV infomercials in many ways resemble documentary films, are often made to advertise more complex products which require a more detailed explanation, and contain numerous testimonials from experts or celebrities. DRTV short form spots, on the other hand, are brief messages about less complex products, can be easily understood and can achieve an immediate response from the viewers. In many DRTV infomercial campaigns for high-value products, the advertisers also produce a short form spot from its longer infomercial to be broadcast more frequently during the day so that the viewers are constantly reminded of the product (see HawthornDirect n.d.).

Regardless of the format, both types of DRTV commercials have one and the same purpose: to boost the product's value and sale. The guiding principal to meet this goal is the AIDA model whose authorship is attributed to E. St. Elmo Lewis, the American advertising and sales pioneer from the late 19 century (see Communication Theory n.d.). AIDA is an acronym for Attention, Interest, Desire, and Action. A commercial should capture consumers' attention, create their interest, convince them that they desire the product to satisfy their needs and motivate them to action, to buy the product. Other important strategies include building credibility by expert testimonials, enhancing the value by offering more than the expected and playing on consumers' emotions and sensory systems by interplay of different linguistic components, music, visual effects and pace of delivery.

Advertisers make great efforts to ensure that they meet all the strategic requirements to persuade viewers to buy. The aim of this paper is to analyse verbal and non-verbal components of persuasive communication in DRTV commercials, in particular DRTV short form spots. We believe that producers of DRTV short form spots need to make use of all possible means of communication in order to meet the criteria of the AIDA model. Our analysis will focus mainly on syntactic, lexical and prosodic features of verbal deliveries of the three DRTV short form spots. We expect that specific syntactic structures emphasised by means of marked intonation will be used to capture the viewers' attention and develop their interest in the advertised products. Due to the shortness of the DRTV short form spots, the producers of these advertisements will also use other, non-verbal strategies to meet the requirements of the AIDA model, such as black and white video clips, as well as written on-screen captions of the main benefits of the products.

In Section 2 we present an overview of relevant previous research in the field of persuasive communication which will also serve as the basis for our research questions. Section 3 is dedicated to the structural and linguistic analyses of three DRTV short form spots. In Section 4 we discuss the results and implications for future research. 


\section{Theoretical Overview and Research Questions}

\subsection{Theoretical Overview}

Analysis of persuasive communication is a very complex task which involves disciplines such as psychology, sociology, marketing, media studies and linguistics. As a result, many different approaches and research methods have been used to analyse and understand the strategies used in persuasive communication. In this paper we focus on different linguistic features which contribute to the persuasiveness of DRTV short form spots.

Persuasion is generally understood as an attempt to change someone's beliefs and attitudes. In commercial business, the purpose of persuasion is to change a person's attitude towards a product or an idea by appealing to their emotions and reactivating positive memories from the past. Petty and Cacioppo (1986) developed the Elaboration Likelihood Model (ELM) according to which there are two routes of processing information: the central and the peripheral route. Persuasion achieved via the central route requires careful and thoughtful processing of information, whereas persuasive results achieved via the peripheral route come from positive associations and emotions. The stimuli received via the peripheral route are more related to the attractiveness of the message than to the logical processing of information.

Language Expectancy Theory (LET), developed by Burgoon and Miller (1985), is another theory of persuasion according to which people verbally communicate in agreement with socially and culturally appropriate expectations. Violations (conscious or accidental) from these norms can trigger either positive or negative reactions. LET presupposes that people have expectations not only about the culturally and socially acceptable behaviour but also about the appropriate language and linguistic strategies which are used with the purpose of persuasion. These linguistic expectations determine whether a message will be positively or negatively accepted - in the latter case, the message will probably be rejected.

LET is based on a close relationship between language and social power. One of the propositions of LET claims that individuals who have credibility, that is, social power, are free to select linguistic strategies to achieve the persuasive goals, whereas those with low credibility and low social power are restricted to more neutral linguistic behaviour.

Several studies examined how particular linguistic features convey a speaker's social power and affect the perception of the message. Lakoff (1975) in her study of language and gender suggested that certain linguistic patterns were typical of female register, which was associated with low social power. O'Barr (1982) in his analysis of courtroom transcripts found out that witnesses with low social power used powerless speech whose characteristics were the use of verbal and nonverbal hesitation markers, hedges and tag questions. These markers were absent in the speech of witnesses with high social power.

Further research of language and power showed that powerful language plays an important role in persuasive communication particularly when transmitted via audio and video channels. Sparks and Areni (2002) discovered that powerful language triggered more favourable attitudes in audio and video messages than powerless language and that speakers were more persuasive when they used powerful instead of powerless language. There are two possible explanations for their findings. First, it is reasonable to believe that the on-line nature of audio and video messages gave little opportunity for an immediate and critical response to the message. Second, in audio 
and video messages an important role is played by the speaker's interpretation and delivery of the message (e.g. intonation, rhythm and speaker's voice quality). In a further study, Areni and Sparks continued to research the relationship between powerful language and persuasion in video and printed communication. They found out that, regardless of the mode of delivery, "speakers using powerful language were more persuasive than speakers using powerless language" $(2005,507)$. In addition, the speech markers in powerless language "had the effect of directing thoughts toward the actual speaker" (Areni and Sparks 2005, 521).

Other studies showed that there is a close connection between linguistic intensity and processing of the message. According to Reinforcement Theory (Insko 1965), linguistic intensity increases the persuasiveness of the message. A study by Craig and Blankenship (2011) showed that the use of linguistic extremity or intensity markers, such as much more, extremely, very and wonderful, as well as strong arguments, increased persuasion as well as credibility. Similarly, Petty and Cacioppo (1986) found that linguistic extremity or intensity markers increase the perception of discrepancy between the initial attitude and the message, which may result in changing the initial attitude. For example, a topic which was initially irrelevant for the addressees may become relevant if presented in a linguistically intense manner.

Linguistic intensity or extremity can be achieved in different ways. One way is by using intensity markers which can be regarded as effective linguistic devices whose purpose is to express attitudes and elicit strong emotions in the addressees. Different authors (Quirk et al. 1987; Georgakopoulou and Goutsos 2004; Tannen 1989) tried to classify intensity markers either according to their morphological categories (e.g. adjectives, adverbs and verbs) or their discourse function (e.g. hedges, emphasizers and amplifiers). In addition to intensity markers, Tannen (1989) recognized also two types of involvement strategies. One was based on sound properties of speech (e.g. rhythm and voice patterns), the other on linguistic interaction with the addressees (e.g. imagery and detail, constructed dialogue, ellipsis and tropes).

There are very few studies which analyse lexical and syntactic forms of linguistic complexity and intensity. Averbeck and Miller (2014) studied the relationship between cognitive complexity on the one hand, and syntactic and lexical complexity on the other. They found that more cognitively complex individuals, i.e. those who had a better ability to think on abstract levels, would prefer lexically complex messages. Individuals who had a greater ability to integrate new information would prefer syntactically complex messages which they also found more persuasive (Averbeck and Miller 2014,87). On the other hand, those individuals who had a better ability to think on concrete as opposed to abstract levels would prefer lexically and syntactically simple messages.

DRTV short form spots are a type of broadcast advertisements where the spoken delivery together with the announcer's voice, sound effects and visual images plays an important role in their persuasiveness. Studies by Chattopadhyay et al. (2003) and Wiener and Chartrand (2014) explored the effects of speech characteristics and voice quality on the efficacy of broadcast advertisements. Chattopadhyay et al. (2003) found that listeners respond less negatively to advertisements where the announcers speak faster than normally and in a lower pitch. Speech rate and low pitch seemed to have a positive influence on the attractiveness, truthfulness and persuasiveness of the advertisement. Wiener and Chartrand came to similar conclusions when they tested consumer response among male and female viewers. They found that female audiences are more responsive to voices and prefer male voices to female. If an advertisement is targeted at a female audience, using a male announcer with a creaky voice will increase the persuasiveness of the advertisement and women will be more likely to buy the advertised product (Wiener and Chartrand 2014, 515). 


\subsection{Research Questions}

On the basis of the above theoretical assumptions we decided to analyse three DRTV short form spots, for one hygiene and two for household products (Easy Feet, slippers for washing feet; Eggies, dishes for cooking hard boiled eggs; XHose, an expandable garden hose) which were made for Highstreet TV, a multi-channel retailer that spans TV, mobile, web, high street and print. The purpose of the analysis was to answer the following research questions:

RQ1: Which verbal and non-verbal strategies are used to meet the requirements of the AIDA model?

RQ2: How do the lexical and the syntactic complexity influence the processing of DRTV short form spots?

RQ3: What is the contribution of intonation to the persuasiveness of DRTV short form spots?

\section{Structural and Linguistic Analyses}

In order to find out which verbal and non-verbal means of persuasion are used to convince the viewers about the benefits of the advertised products and encourage them to buy (RQ1), we carried out the structural and linguistic analyses of the three DRTV short form spots. First we looked at their structure in terms of duration, speed of delivery, number of words and sentences, as well as the interplay between the visual (action on screen), spoken and written modes (written on-screen captions).

\subsection{Structure of DRTV Short Form Spots}

The three analysed DRTV short form spots have many features in common. Table 1 summarizes the main structural features: they are of similar length in terms of time, number of sentences and number of words. The products' names occur with a high frequency and at similar average intervals, both in terms of words and seconds.

TABLE 1. Comparison of structural features of three DRTV short form spots.

\begin{tabular}{|l|l|l|l|}
\hline & EGGIES & EASY FEET & XHOSE \\
\hline Length & $1^{\prime} 17^{\prime \prime}$ & $1{ }^{\prime} 30^{\prime \prime}$ & $1 ' 58 ”$ \\
\hline Number of sentences & 26 & 21 & 27 \\
\hline Number of words & 234 & 270 & 331 \\
\hline Speed of delivery & $3 \mathrm{wds} . / \mathrm{sec}$. & $3 \mathrm{wds} . / \mathrm{sec}$. & $2.8 \mathrm{wds} . / \mathrm{sec}$. \\
\hline Black \& white inserts & $2(9 \mathrm{sec})$ & $2(12 \mathrm{sec})$ & $2(7 \mathrm{sec})$ \\
\hline Occurrence of product's name & 8 & 8 & 14 \\
\hline Intervals of product's name (average) & $28.7 \mathrm{words}$ & $28.3 \mathrm{words}$ & $22.4 \mathrm{words}$ \\
& $9.6 \mathrm{sec}$ & $10 \mathrm{sec}$ & $8.1 \mathrm{sec}$ \\
\hline Written on-screen captions (occurrence) & 21 & 20 & 22 \\
\hline
\end{tabular}

They all exhibit the same problem-solution pattern in which the problem is filmed in the black and white technique, whereas the solution is presented in bright and happy colours with excited faces of actors enjoying the benefits of the advertised product. In spite of the shortness of the three 
DRTV short form spots, the advertisers follow the principle that potential customers have to be reminded of the problem several times. Hence the black and white inserts appear twice in all three DRTV short form spots: in the beginning and in the second half of the spot (see Appendix 1).

Another common feature to all three DRTV short form spots is the written support to the auditory and visual information. At the same time that the viewers see the action on the screen they listen to the narrator while the main benefits of the advertised product appear written on the screen (see Example 1 and Appendix 1). Bright colours, capital letters and exclamation marks are regularly used. The viewers' sensory systems are thus exposed to three different types of stimuli which trigger three different cognitive processes: listening, watching and reading.

Example 1. Interplay of visual and + language in Eggies. ${ }^{l}$

And here's something really handy.

COOKS FLAT!

DECORATE

Because Eggies cook flat on the bottom, they're easy to decorate.

\section{WITHOUT A SINGLE SHELL!}

Now you can enjoy delicious hard or soft boiled eggs without peeling a single shell.

\subsection{Linguistic Analysis}

\subsubsection{Syntactic and Grammatical Structures}

The three DRTV short form spots also exhibit very similar patterns regarding the use of syntactic and grammatical structures. The first step in the AIDA model is to capture consumers' attention. In terms of the contents of the commercial, this is achieved by presenting a problem that the advertised product can eliminate. A syntactic structure that is usually used to elicit the addressee's attention is an exclamation. The other frequently used attention-seeking device, especially in faceto-face interactions, is the question-answer sequence. Both techniques are used in the three DRTV short form spots. Eggies begins with an exclamation which is immediately followed by a negation of the message:

Example 2. Opening of Eggies.

Messy shells, broken whites, dirty hands! (exclamation)

Well, not anymore. (negation)

Easy Feet opens with a question-answer sequence which is immediately followed by an affirmative statement expressing a problem and a negative statement indicating the end of the problem and preparing the viewer for the solution:

Example 3. Opening of Easy Feet.

How do you clean your feet? (question)

You bend, stretch any you can't reach. (answer)

Keeping your tired feet looking and smelling great can be such a chore. (statement)

But not anymore. (negation)

Written text which appears on screen is presented in capital letters. 
XHose begins with even two exclamations:

Example 4. Opening of XHose.

The XHose! The incredible expanding hose! (exclamation)

The second step in the AIDA model is to create interest for the product in consumers; in other words, to introduce the solution to the problem. In Eggies and Easy Feet this is done by using an introductory pattern typically used in official public introductions of people where the speaker states the name, affiliation and achievements of the person in question. This is realised by statements.

Example 5. Creation of interest in Eggies.

Introducing Eggies from New Innovations.

The fast, fun and easy way to cook hard or soft boiled eggs without the shell.

Example 6. Creation of interest in Easy Feet.

Introducing Easy Feet from New Innovations.

The easy and convenient way to clean, massage and exfoliate from heel to toe.

In $X$ Hose the interest is created by an invitation (realised by an imperative), followed by a demonstration of the hose ( 2 imperative-indicative sentences) and another exclamation:

Example 7. Creation of interest in XHose.

Watch this! (imperative)

Turn the water on and the XHose automatically expands to up to three times its original length. Turn the water off and as the water drains, the XHose automatically starts contracting until it's contracted to a very small size. (imperative-indicative) Amazing! (exclamation)

Step three in the AIDA model is to convince the consumer to desire the product. This is the main part of the spot. In all three DRTV short form spots this is achieved by means of enumeration and repetition of the main benefits of the products. The typical syntactic pattern is a combination of statements and imperatives, in the case of XHose also exclamations.

Example 8. Development of desire in XHose.

Ordinary fifty-foot hoses can be heavy. The XHose is incredibly light. A fifty-foot

XHose weighs only about a pound. (3 statements)

And what a dream to handle! (exclamation)

Just turn the water on and the XHose quickly expands up to three times its length as you effortlessly guide it where you need to go. (imperative-indicative sentence)

Imagine using a hose that is this light and this easy to handle! (imperative)

The last step in the AIDA model is to motivate the consumers to action, that is, to buy the product. In all three DRTV short form spots this is achieved by means of imperatives. In the case of Eggies, the imperative is preceded by a question.

Example 9. Motivating to buy in Eggies, Easy Feet and XHose.

Got an egg? Get an Eggies! (Eggies) 
Clean, massage and exfoliate with the safe and convenient Easy Feet! (Easy Feet)

Get your very own XHose, the incredible expanding hose, today! (XHose)

In addition to the four steps of the AIDA model, it is also important that an effective commercial convinces viewers by means of credibility and develops a personal relationship with potential consumers. There is more time for achieving credibility by means of personal or expert testimonials in infomercials than in DRTV short form spots. ${ }^{2}$ Instead credibility in short form spots is developed by means of picture rather than grammatical and lexical structures.

Personal relation between advertisers and consumers is manifested by means of a direct address in the form of the second person pronoun you or possessive adjective your, as well as the imperative mood.

Table 2 summarizes the syntactic patterns and grammatical features used to realise the AIDA model, including the personal relation.

TABLE 2. Comparison of syntactic and grammatical features.

\begin{tabular}{|l|l|l|l|}
\hline AIDA MODEL & EGGIES & EASY FEET & XHOSE \\
\hline $\begin{array}{l}\text { ATTENTION } \\
\text { problem) }\end{array}$ & $\begin{array}{l}\text { Exclamation- } \\
\text { Negation }\end{array}$ & $\begin{array}{l}\text { Question-Answer- } \\
\text { Statement- } \\
\text { Negation }\end{array}$ & Exclamation \\
\hline $\begin{array}{l}\text { INTEREST } \\
\text { (solution) }\end{array}$ & Statement & Statement & $\begin{array}{l}\text { Imperative- } \\
\text { Imperative+indicative } \\
\text { statements-Exclama- } \\
\text { tion }\end{array}$ \\
\hline $\begin{array}{l}\text { DESIRE } \\
\text { (enumeration and repetition } \\
\text { of the product's benefits) }\end{array}$ & $\begin{array}{l}\text { Statements- } \\
\text { Imperatives } \\
\text { ACTION }\end{array}$ & $\begin{array}{l}\text { Statements- } \\
\text { Imperatives }\end{array}$ & $\begin{array}{l}\text { Statements- } \\
\text { Imperatives- } \\
\text { Exclamations }\end{array}$ \\
\hline $\begin{array}{l}\text { PERSONAL RELATION } \\
\text { Question-Imperative }\end{array}$ & $\begin{array}{l}\text { Imperative } \\
\text { Youlyour }\end{array}$ & $\begin{array}{l}\text { Imperative } \\
\text { Youlyour }\end{array}$ & $\begin{array}{l}\text { Imperative } \\
\text { Youlyour }\end{array}$ \\
\hline
\end{tabular}

Table 3 presents the number of occurrences of sentence types used in the three DRTV short form spots. As expected, the highest frequency of occurrence can be observed in statements which are immediately followed by imperative structures. Since the function of the imperative is to create a personal relation between the speaker and the addressee, the high frequency of occurrence is not surprising. Although the imperatives are more frequent in the Eggies and the XHose than in the Easy Feet DRTV short form spots, this does not mean that the last is less personal. On the contrary, the Easy Feet spot has the highest number of incidence regarding the use of the personal pronoun you and the 2 person possessive adjective your, which also contribute to the personal relationship. 
TABLE 3. Number of occurrences of sentence types and 2 person address items.

\begin{tabular}{|l|l|l|l|}
\hline & EGGIES $(\mathrm{n}=26)$ & EASY FEET $(\mathrm{n}=21)$ & XHOSE $(\mathrm{n}=27)$ \\
\hline IMPERATIVE & $8(30.8 \%)$ & $4(19 \%)$ & $8(29.6 \%)$ \\
\hline EXCLAMATION & $1(3.8 \%)$ & 0 & $4(14.8 \%)$ \\
\hline STATEMENT & $16(61.6 \%)$ & $16(76.2 \%)$ & $15(55.6 \%)$ \\
\hline QUESTION & $1(3.8 \%)$ & $1(4.8 \%)$ & 0 \\
\hline YOU/YOUR & 13 & 19 & 11 \\
\hline
\end{tabular}

\subsubsection{Lexical Analysis}

In order to establish the influence of the lexical and syntactic complexity upon the processing of DRTV short form spots (RQ2), the texts of the three DRTV short form spots were submitted to two on-line computer programmes which also measure lexical and syntactic complexity: VocabProfile (Cobb n.d.), and Coh-Metrix 3.0 (McNamara 2005). ${ }^{3}$

VocabProfile (VP) performs lexical text analysis by grouping the words in four categories according to their frequency of occurrence in English. In Category 1 there are the first 1,000 most frequent English words, Category 2 consists of the next 1,000 most frequent words in English, in Category 3 there are 550 words which are most frequent in academic texts and Category 4 is made of words which are not found on other lists. The tool was developed to measure the proportion of high and low frequency words used by native speakers of English in written texts. Table 4 presents the results obtained from VocabProfile analysis of the three DRTV short form spots.

TABLE 4. VocabProfile analysis of 3 DRTV short form spots.

\begin{tabular}{|l|l|l|l|}
\hline & EGGIES & EASY FEET & XHOSE \\
\hline $1-1000$ wds & $\mathbf{6 9 . 6 2} \%$ & $\mathbf{6 9 . 0 9} \%$ & $75.67 \%$ \\
Function: & $36.71 \%$ & $42.91 \%$ & $43.03 \%$ \\
Content: & $32.91 \%$ & $26.18 \%$ & $32.64 \%$ \\
\hline $1001-2000$ wds & $16.03 \%$ & $22.18 \%$ & $5.04 \%$ \\
\hline Academic wds & $1.69 \%$ & $2.18 \%$ & $5.34 \%$ \\
\hline Off-List wds & $12.66 \%$ & $6.55 \%$ & $13.95 \%$ \\
\hline
\end{tabular}

If we accept the claim that "a typical NS [native speaker] result is 70-10-10-10, or 70\% from first 1000, 10\% from second thousand, 10\% academic, and 10\% less frequent words" (Cobb n.d.), then we find that the three texts do not altogether meet this formula. The percentage of the most frequent English words (Category 1) is indeed around 70\% in all three texts, and the percentage of the second most frequent English words (Category 2) is in the Eggies and Easy Feet texts above, whereas in the XHose text it is below the native speaker's result. In spite of the fact that the percentage of the words in Categories 3 and 4 are well below the expectations of a native speaker text, we can conclude that the three DRTV texts exhibit lexical features that a native speaker of English can understand. But this does not tell us a lot about the ease with which these texts are processed by a native speaker.

For a similar lexical analysis of newspaper articles in reading comprehension tests cf. Ilc and Stopar (2015). 
In order to find out the level of readability and complexity of the three texts, we submitted them to the analysis by the Coh-Metrix tool, which is an automated textual assessment tool devised to provide different measures at the level of the text, paragraph, sentence or word.

Coh-Metrix provides a large number of different measures, from purely descriptive (e.g. number of words, sentences, paragraphs) to referential. The purpose is to measure cohesion, lexical diversity, syntactic pattern complexity and finally readability by means of Flesch-Kincaid Grade Level.

Due to the limited duration of DRTV short form spots (max. 120 seconds) in which the advertised product should be effectively presented by meeting all four criteria of the AIDA model, it is expected that it will contain lexical and syntactic features which enable easy and quick processing of information.

From the long list of different measures provided by Coh-Metrix, we selected those which play a crucial role in processing of information. Table 5 presents the results obtained from the CohMetrix tool.

TABLE 5. Coh-Metrix results for three DRTV short form spots.

\begin{tabular}{|l|l|l|l|}
\hline MEASURES & EGGIES & EASY FEET & XHOSE \\
\hline Sentence length (number of words, mean) & 8.207 & 11.5 & 11.655 \\
\hline Word length (number of syllables, mean) & 1.324 & 1.312 & 1.441 \\
\hline Lexical diversity (type-token ratio, all words) & 0.504 & 0.48 & 0.485 \\
\hline Lexical diversity (MTLD, all words) & 81.012 & 65.638 & 85.967 \\
\hline Age of acquisition of content words & 222.875 & 256.84 & 283.711 \\
\hline Familiarity for content words & 577.044 & 585.384 & 563.946 \\
\hline Concreteness for content words & 419.779 & 425.574 & 421.888 \\
\hline Imageability for content words & 443.929 & 456.12 & 443.574 \\
\hline Polysemy for content words & 4.338 & 4.655 & 4.309 \\
\hline Syntactic pattern density (noun phrase) & 294.118 & 311.594 & 269.231 \\
\hline Syntactic pattern density (verb phrase) & 201.681 & 199.275 & 198.225 \\
\hline Syntactic pattern density (adverbial phrase) & 33.613 & 39.855 & 62.13 \\
\hline Syntactic pattern density (preposition phrase) & 67.227 & 86.957 & 73.965 \\
\hline Syntactic pattern density (agentless passive voice) & 0 & 0 & 5.917 \\
\hline Syntactic pattern density (negation) & 4.202 & 10.87 & 5.917 \\
\hline Syntactic pattern density (gerund) & 16.807 & 21.739 & 26.627 \\
\hline Syntactic pattern density (infinitive) & 18.807 & 18.116 & 17.751 \\
\hline Readability (Flesch Reading Ease) & 86.495 & 84.167 & 73.097 \\
\hline Readability (Flesch-Kincaid Grade level) & 3.234 & 4.377 & 5.959 \\
\hline
\end{tabular}

Sentence and word lengths have an important influence upon the difficulty of the text. It has been established that sentences with more words tend to have a more complex syntax and are as such more difficult to process. Similarly, words with more syllables are more difficult to process 
(especially in reading). The results obtained by Coh-Metrix show that the average length of sentences is between 8 and 11 words which are relatively short (one syllable and a half long). Although DRTV short form spots rely primarily on spoken delivery where the interpretation may help or hinder the decoding process (see 3.3), the shortness of sentences and words should make the processing of the message easy.

According to McNamara et al. $(2014,67)$ "lexical diversity refers to the variety of unique words (types) that occur in a text in relation to the total number of words (tokens)". In the case of the three DRTV short form spots we can observe a relatively low lexical diversity (around 0.5). This means two things: a high degree of cohesion and a repetition of the same word several times in the text. MTLD (Measure of Textual Lexical Density) is "calculated as the mean length of sequential word strings in a text that maintain a given TTR [type-token ratio] value" (McNamara et al. 2014, 67). According to MTLD, the Easy Feet spot has a significantly lower text lexical diversity than the other two spots and hence it is even easier to process than the other two DRTV short form spots.

Another important set of lexical characteristics which can make a text easier or more difficult to process are the age of acquisition, familiarity, concreteness, imageability and polysemy of content words.

The age of acquisition of content words specifies the age at which the word first appears in a child's language. Results are presented on a scale from 100 to 700, where words with a higher age of acquisition score are acquired later in life. The age of acquisition of content words in the three DRTV short form spots is relatively low (222.875-283.711), which indicates that the texts are easy to decode.

Familiarity of content words is an important indicator since texts with many familiar words are decoded more quickly. Results are presented on a scale from 100 to 700, where more familiar words have a higher score. Familiarity of content words in the three DRTV short form spots is slightly below 600 , which means that the three texts are very easy to process.

The concreteness index measures how concrete or non-abstract words are. Most concrete content words are those which refer to things that can be touched, heard or tasted. Results are presented on a scale from 100 to 700, where higher scores signify more concrete content words. The scores for the three DRTV short form spots are slightly above 400, which means that the majority of content words are very concrete and hence relatively easy to decode.

Imageability index is in close relation with concreteness of content words and it indicates the ease or difficulty with which one constructs mental images of content words. Higher scores on a scale from 100 to 700 indicate content words which are easy to imagine. The results for the three DRTV short form spots are also above 400, which means that the content words are relatively easy to imagine.

Polysemy index refers to the number of meanings that a content word may have. Coh-Metrix provides average polysemy for content words. According to McNamara $(2014,75)$ more frequent words tend to have more meanings. The scores for the three DRTV short form spots are all over 4 , signifying the usage of more frequent content words.

In addition to lexical diversity and familiarity of lexical items used in texts, the difficulty of decoding also depends on the syntactic complexity which is in Coh-Metrix measured by the 
incidence of particular syntactic patterns and phrase types. A text with a high number of noun and verb phrases tends to be informationally dense with complex syntax (McNamara et al. 2014, 72). Other syntactic patterns which make the decoding of a text more difficult are negation, agentless passive voice, and the use of gerunds and infinitives.

The noun and verb phrase density in the three DRTV short form spots is high especially when compared with the occurrence of adverbial and preposition phrases. The incidence of gerunds and infinitives is also quite high, whereas the incidence of negation is highest in the Easy Feet spot. Agentless passive voice occurs only in the XHose spot.

Results from the above indices indicate that the texts of the three DRTV short form spots are relatively easy to process which is mainly due to short sentences and words, familiarity, concreteness and imageability of content words. On the other hand, the density of noun and verb phrases makes the texts informationally condensed and as such more difficult to process.

Taking all these indices into consideration, Coh-Metrix tool provides two measures of text ease or difficulty. These are Flesh-Kincaid Grade Level and Flesh Reading Ease. They take into account the word and sentence complexity and can predict sentence understanding and reading speed. Flesh Reading Ease is measured on a scale from 0 to 100. High results indicate that a text is easy to understand. In fact, the results for the texts of the three DRTV short form spots are from 73.097 to 86.495 , indicating that these texts are easily understood by 11 to 13 -year-old readers. The Flesh-Kincaid Grade Level translates the Flesh Reading Ease results into a US grade level. The three texts of DRTV short form spots rank from grade 3 to nearly grade 6 . In other words, they are easily processed by children from age 8 to 12 .

\subsection{Prosodic Analysis}

Due to the fact that DRTV short form spots are delivered via spoken channel, analysis of intonation and its influence on the persuasiveness of the commercials is equally important as the analysis of lexical and syntactic features. If we take into consideration also the assumption that the peripheral routes of persuasion influence the addressees' emotions, the role of different prosodic features, such as pitch height and movement, volume and speed, is of utmost importance. In Section 2 we presented findings of two studies on the voice quality of narrators and speed of delivery in broadcast advertisements according to which fast delivery and lower pitched voices tend to be more persuasive.

The purpose of our prosodic analysis was to establish the contribution of tonality, tonicity and tunes to the recognizable style of delivery in DRTV short form spots (RQ3).

\subsubsection{Tonality}

Tonality (i.e. division into intonation phrases - IP) and tonicity (i.e. the nucleus placement) are two important processes by means of which speakers package information into small chunks and give prominence to important pieces of information. In unmarked contexts, tonality often follows grammatical division into clauses, whereas in marked contexts, IP boundaries may occur between phrases, words or even syllables.

Table 6 compares the three DRTV short form spots in terms of the length, number of words, number of intonation phrases and the distribution of content words per intonation phrase. 
TABLE 6. Length and structure of IPs.

\begin{tabular}{|l|l|l|l|}
\hline ENGLISH & EGGIES & EASY FEET & XHOSE \\
\hline TIME & 1 '17” & 1 '30” & 1 '58” \\
\hline WORDS & 234 & 270 & 331 \\
\hline IP & $71(=3.3 \mathrm{w} / \mathrm{IP})$ & $72(=3.7 \mathrm{w} / \mathrm{IP})$ & $95(=3.5 \mathrm{w} / \mathrm{IP})$ \\
\hline $\mathbf{1} \mathbf{C W} / \mathrm{IP}$ & $21(29.6 \%)$ & $19(26.5 \%)$ & $26(27.4 \%)$ \\
\hline $\mathbf{2} \mathbf{C W} / \mathrm{IP}$ & $29(40.8 \%)$ & $28(38.9 \%)$ & $41(43.2 \%)$ \\
\hline $\mathbf{3} \mathbf{C W} / \mathrm{IP}$ & $17(24 \%)$ & $14(19.4 \%)$ & $16(16.8 \%)$ \\
\hline $\mathbf{4} \mathbf{C W} / \mathbf{I P}$ & $4(5.6 \%)$ & $7(9.7 \%)$ & $10(10.5 \%)$ \\
\hline $\mathbf{5}$ CW/IP & - & $4(5.5 \%)$ & $2(2.1 \%)$ \\
\hline NUCLEUS (N) & $24(33.8 \%)$ & $21(29.2 \%)$ & $26(27.4 \%)$ \\
\hline HEAD+N & $47(66.2 \%)$ & $49(68 \%)$ & $62(65.2 \%)$ \\
\hline OTHER & 0 & $2(2.8 \%)$ & $7(7.4 \%)$ \\
\hline
\end{tabular}

The three DRTV short form spots range from 77 to 118 seconds in time length and have from 234 to 331 words. The texts are divided into 71,72 and 91 IPs, averaging 3.3 to 3.7 words per IP. More important than the average number of words per IP is the number of content words (CWs) per IP since these affect the density of the message. In this respect the majority of IPs contain two CWs per phrase (Eggies: 40.8\%, Easy Feet: 38.9\%, XHose: 43.2\%). Intonation phrases which have only one CW come second (Eggies: 29.6\%, Easy Feet: 26.5\%, XHose: 27.4\%), whereas IPs with three CWs are in the third place (Eggies: 24\%, Easy Feet: 19.4\%, XHose: 16.8\%). The Eggies DRTV spot contains only $5.6 \%$ of IPs with four CWs and no IP with more than four CWs. The Easy Feet and the XHose DRTV short form spots have 15.2\% and $12.6 \%$ of IPs with four or even five CWs.

Since each IP has at least one pitch-prominent syllable, marked tonality produces utterances which are felt as extremely emphatic and appropriate only for limited contexts of interaction. The large number of IPs and their shortness in the three DRTV short form spots suggest an emphatic delivery of the message, as demonstrated in Example 10, in which one sentence is divided into 5 IPs.

Example 10.

Fast $\mid$ and fresh egg sandwiches | or simply | slice an egg| over a scrumptious salad $\|$

In addition, an IP can have only the nucleus or it can consist of a pre-nuclear pitch prominent segment (head) and the nucleus (for further discussion see 3.3.3). The results presented in Table 6 indicate that the majority of IPs contain two pitch prominent syllables: the head and the nucleus (Eggies: 66.2\%, Easy Feet. 68\%, XHose: 65.2\%) which makes the interpretation even more marked.

\subsubsection{Tonicity}

Analysis of tonicity further supports the assumption of heavily marked interpretation. It has already been established that some words, phrases and even clauses are repeated in the three DRTV texts at regular intervals. A closer look at the location of the nucleus in these repeated structures indicates that they are always spoken with the nucleus located on the same $\mathrm{CW}$, which is in contradiction with the basic principle of tonicity, i.e. the nucleus should occur on a $\mathrm{CW}$ 
expressing new information. Table 7 presents the tonicity and nuclear tones of the products' names and some very frequently occurring CWs.

TABLE 7. Tonicity and nuclear tones of products' names and frequent CWs.

\begin{tabular}{|l|l|l|l|l|}
\hline IP & $\begin{array}{l}\text { Number of } \\
\text { occurrences }\end{array}$ & Nucleus & Fall & Fall-Rise \\
\hline Eggies $^{3}$ & 8 & $6(75 \%)$ & $4(66.7 \%)$ & $2(33.3 \%)$ \\
\hline Egg & 14 & $8(57.1 \%)$ & $6(75 \%)$ & $2(25 \%)$ \\
\hline Shell & 5 & $5(100 \%)$ & $4(80 \%)$ & $1(20 \%)$ \\
\hline Easy Feet & 8 & $5(62.5 \%)$ & $4(80 \%)$ & $1(20 \%)$ \\
\hline Feet & 10 & $7(70 \%)$ & $6(85.7 \%)$ & $1(14.3 \%)$ \\
\hline Foot & 3 & $3(100 \%)$ & $3(100 \%)$ & 0 \\
\hline Toe & 3 & $3(100 \%)$ & $2(66.7 \%)$ & $1(33.3 \%)$ \\
\hline XHose & 14 & $12(85.7 \%)$ & $7(58.3 \%)$ & $5(41.7 \%)$ \\
\hline Hose & 10 & $5(50 \%)$ & $3(60 \%)$ & $2(40 \%)$ \\
\hline
\end{tabular}

We can see that the products' names occur very frequently and function as nuclei in very high percentages (Eggies: 75\%, Easy Feet: 62.5\%, XHose: 85.7\%). In the Eggies DRTV spot egg and shell are the other two most frequently occurring CWs functioning as nuclei in $57.1 \%$ (egg) and $100 \%$ (shell). In the Easy Feet DRTV spot the three most frequently occurring CWs functioning as nuclei are feet ${ }^{5}(70 \%)$, foot $(100 \%)$ and toe $(100 \%)$, whereas in the XHose DRTV spot the content word hose is chosen as nucleus in 50 per cent of its occurrences.

\subsubsection{Tones and Tunes}

In English there are five basic pitch movements (tones) which can be realized on the nuclear syllable: the fall, the rise, the fall-rise, the rise-fall and the level. Not all tones occur in the English language with the same frequency. According to Cruttenden $(2014,291)$ the falling tones (regardless of the pitch height) are generally estimated to account for 50 per cent of all nuclear tones, whereas the simple rise and the fall-rise account for a further 40 per cent. The distribution of the tones in the three DRTV short form spots as presented in Table 8 supports this estimated frequency of occurrence of English nuclear tones.

TABLE 8. Tones and their frequency of occurrence in the three DRTV short form spots.

\begin{tabular}{|l|l|l|l|}
\hline TONE & $\begin{array}{l}\text { EGGIES } \\
(\mathrm{N}=71)\end{array}$ & $\begin{array}{l}\text { EASY FEET } \\
(\mathrm{N}=72)\end{array}$ & $\begin{array}{l}\text { X HOSE } \\
(\mathrm{N}=95)\end{array}$ \\
\hline FALL & $\mathbf{4 7}(\mathbf{6 6 . 2} \%)$ & $\mathbf{4 2}(\mathbf{5 8 . 4} \%)$ & $\mathbf{7 0}(\mathbf{7 3 . 7} \%)$ \\
\hline High fall & $41(57.7 \%)$ & $32(44.5 \%)$ & $55(57.9 \%)$ \\
\hline Low fall & $6(8.5 \%)$ & $10(13.9 \%)$ & $15(15.8 \%)$ \\
\hline RISE & $\mathbf{8 ( 1 1 . 3 \% )}$ & $\mathbf{1 2}(\mathbf{1 6 . 3} \%)$ & $\mathbf{5 ( 5 . 3 \% )}$ \\
\hline High rise & $7(9.9 \%)$ & $7(9.7 \%)$ & $1(1.1 \%)$ \\
\hline Low rise & $1(1.4 \%)$ & $5(6.9 \%)$ & $4(4.2 \%)$ \\
\hline FALL-RISE & $\mathbf{1 0 ( 1 4 \% )}$ & $\mathbf{7 ( 9 . 7 \% )}$ & $\mathbf{1 5}(\mathbf{1 5 . 8} \%)$ \\
\hline
\end{tabular}

\footnotetext{
The underlined syllables indicate the primary stress.

CWs feet and hose occur independently and not as part of the compound phrases Easy Feet and XHose.
} 


\begin{tabular}{|l|l|l|l|}
\hline RISE-FALL & 0 & 0 & $2(2.1 \%)$ \\
\hline LEVEL & $6(8.5 \%)$ & $11(15.3 \%)$ & $3(3.1 \%)$ \\
\hline
\end{tabular}

Table 8 also shows that the most frequent tone is the falling tone which is the expected nuclear tone not only in terms of its general frequency of occurrence in the English language, but also in terms of the sentence types, i.e. statements, imperatives and exclamations, for which this is the default tone (Wells 2006) and which prevail in the three DRTV short form spots.

In addition to the grammatical meaning of nuclear tones, which is manifested by the relationship between nuclear tones and sentence types, we can also find justification for the prevailing occurrence of falling nuclear tones in their pragmatic and discourse meanings. According to O'Connor and Arnold (1973) the falls indicate definiteness, confidence and involvement. The high fall, which is the prevailing form of the fall in the three DRTV short form spots, expresses a high degree of involvement on the part of the speaker. According to Brazil (1997), the discourse meaning of the fall is to express something which is not yet part of the common ground between the speaker and the listener. In other words, it is used to proclaim new information.

Almost one quarter of all nuclear tones in DRTV short form spots are the non-falling ones (i.e. rise and fall-rise), among which the fall-rise has a higher frequency of occurrence than the simple rise (with the exception of the Easy Feet spot where the simple rise occurs more frequently than the fall-rise).

In line with O'Connor and Arnold (1973) and Wells (2006), the non-falling nuclear tones express non-finality or continuity. The prevailing occurrence of the fall-rise nuclear tones in the Eggies and the XHose spots can be best explained by referring to Brazil's discourse approach to intonation according to which the non-falling tones are used to refer to pieces of information which are already part of the common ground. In other words, they have the anaphoric cohesive function, as opposed to the falling tones whose function is cataphoric. And indeed, the fall-rises occur on pieces of information which are repeated at regular intervals as shown. In Example 11, from the XHose DRTV spot, we can see that the product's name functions twice as the nucleus: in the first IP a fall (I) is used which presents XHose as new information, whereas in the fifth IP a fall-rise $(V)$ is used, making the anaphoric cohesive reference to the common ground knowledge that exists between the speaker and listener.

Example 11.

The $\underline{X}$ Hose | con'tracts to an inlcredibly small size | that 'stores leasily.

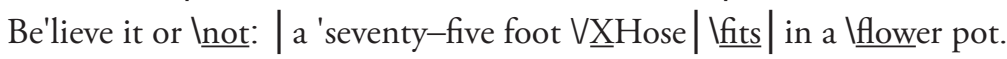

In the pragmatic approach to the study of intonation, the fall-rise is often referred to as the implicational fall-rise whose function is to express contrast, reservations and doubt (O'Connor and Arnold 1973; Wells 2006).

Example 12 illustrates the interplay of the discourse and pragmatic meanings of the fall $(\backslash)$ and the fall-rise $(V)$. The fall-rise nuclear tone used in the second IP is the so-called implicational fall-rise since it implies that by using the Eggies cooking dish, peeling of hard boiled eggs is no longer necessary. The use of the proclaiming falling nuclear tone in the third and the forth IP introduces information which may be new to the listeners, i.e. peeling a hard boiled egg is messy and takes time. 
Example 12.

$/$ Peeling just lone egg the $\underline{\text { regular way } \mid \text { can be } \underline{\text { messy }} \mid \text { and 'take ltime/ }}$

Nearly seventy per cent of IPs in the three DRTV short form spots consist of more than two CWs per IP. In fact, they consist of two pitch-prominent syllables. O'Connor and Arnold (1973) refer to the syllables from the onset as the head and recognize four different types: high, low, falling and rising. Together with the nuclear tones they form ten different tunes.

Table 9 presents the most frequent combinations of the head and the nuclear tone in the three DRTV short form spots.

TABLE 9. Heads and tones.

\begin{tabular}{|l|l|l|l|}
\hline HEAD + TONE & $\begin{array}{l}\text { EGGIES } \\
(\mathrm{N}=47)\end{array}$ & $\begin{array}{l}\text { EASY FEET } \\
(\mathrm{N}=49)\end{array}$ & $\begin{array}{l}\text { X HOSE } \\
(\mathrm{N}=62)\end{array}$ \\
\hline HIGH HEAD + FALL & $\mathbf{1 5}(\mathbf{3 1 . 9} \%)$ & $\mathbf{1 8}(36.7 \%)$ & $\mathbf{3 1}(\mathbf{5 0 . 1} \%)$ \\
\hline High Head+High Fall & $10(21.3 \%)$ & $10(20.4 \%)$ & $21(34 \%)$ \\
\hline High Head+ Low Fall & $5(10.6 \%)$ & $8(16.3 \%)$ & $10(16.1 \%)$ \\
\hline RISING HEAD + HIGH FALL & $\mathbf{1 5 ( 3 1 . 9 \% )}$ & $\mathbf{9 ( 1 8 . 3 \% )}$ & $\mathbf{3 ( 4 . 8 \% )}$ \\
\hline FALLING HEAD + FALL-RISE & $\mathbf{5 ( 1 0 . 6 \% )}$ & $\mathbf{2 ( 4 . 1 \% )}$ & $\mathbf{4}(\mathbf{6 . 5} \%)$ \\
\hline FALLING HEAD + HIGH FALL & $\mathbf{7 ( 1 4 . 9 \% )}$ & $\mathbf{4}(\mathbf{8 . 2} \%)$ & $\mathbf{1 0}(\mathbf{1 6 . 1} \%)$ \\
\hline OTHER & $\mathbf{5 ( 1 0 . 6 \% )}$ & $\mathbf{1 6}(\mathbf{3 2 . 6} \%)$ & $\mathbf{1 4}(\mathbf{2 2 . 5 \% )}$ \\
\hline
\end{tabular}

The table shows that the most frequently occurring tune in the DRTV short form spots consists of the high head and a fall. This is the default tune for statements, imperatives and exclamations. The second most frequent tune in the Eggies and the Easy Feet short form spots consists of the rising head and the high fall. This is regarded as the marked version of the former because of its gradually ascending pitch movement, beginning very low in the pitch range and rising to the upper half of it from where the high fall begins. Due to this extensive pitch movement, O'Connor and Arnold associate with it the attitude of "protest, as if the speaker were suffering under a sense of injustice" (1973, 73). Example 13 illustrates the opening of the Eggies short form spot where four successive IPs all contain the rising head followed by the high falling nuclear tone. This is a good example of an implied protest of the speaker against the traditional cooking of eggs.

\section{Example 13.}

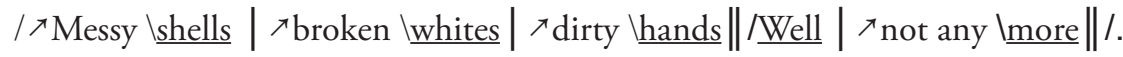

When the same tune is used in commands, O'Connor and Arnold claim that they "are not so much orders as recommendations for a course of action" $(1973,74)$. And indeed, the Eggies spot ends with a recommendation uttered with this tune, as illustrated in Example 14.

Example 14.

/ $\nearrow$ Get an IEggies!/

\section{Discussion}

The purpose of the structural and the linguistic analyses of the three DRTV short form spots was 
to provide answers to three research questions. Our first research question addressed the issue of verbal and non-verbal strategies used to meet the requirements of the AIDA model. We found that all three DRTV short form spots share a number of identical verbal and non-verbal strategies. In addition to similar length, number of words and sentences and regular repetitions of the products' names, they also appeal to the viewers' sensory systems by exposing them to three different types of stimuli: auditory, visual and pictorial. Since all three stimuli represent the same idea, we can assume that the viewers are saturated with that information. Whether that increases the persuasiveness of the advertisement and convinces the viewers to buy the product remains to be investigated.

The first step in the AIDA model is to capture consumers' attention. In all three DRTV short form spots examined this is achieved by presenting a problem and offering a solution. The nonverbal strategy used to present the problem is by means of a black and white video clips. The verbal strategies include exclamations and question-answer sequences.

Developing interest for the product, which is the second step in the AIDA model, is verbally and non-verbally achieved by presenting a solution to the problem. The typical syntactic structures are statements, whereas the non-verbal strategy includes a shift from black and white to colour video clips.

The central part of the DRTV short form spots is dedicated to convince the viewers that they desire the product. Verbally this is achieved by means of enumeration and several repetitions of the products' qualities and benefits by using statements, imperatives and even exclamations. Nonverbal strategies include demonstration of the products' qualities and their positive influence upon the users, who all look happy, relaxed, and who are smiling and enjoying the benefits of the advertised products.

The default syntactic structure to motivate to action is the imperative, which is used in all three DRTV short forms spots to meet the last requirement of the AIDA model.

Credibility and developing a personal relationship with consumers are additional and equally important strategies. The former is mainly achieved by means of non-verbal strategies, whereas the latter is manifested verbally by means of the second person pronoun you or possessive adjective your, as well as the imperative mood.

Our second research question dealt with the influence of the lexical and the syntactic complexity upon the processing of DRTV short form spots. According to the Lexical Expectancy Theory and research of Averbeck and Miller (2014), it is expected that lexically and syntactically complex texts will be more difficult to process, but at the same time they will be more persuasive. The results obtained from the Coh-Metrix on-line tool indicate that the texts of the three DRTV short form spots contain short sentences and words which make the processing of information easy. Familiarity, concreteness and imageability of content words also add to the ease of information processing. The only factor which makes the decoding process a little more difficult is the density of noun and verb phrases because of which the texts are informationally condensed. According to Flesh Reading Ease and Flesh-Kincaid Grade Level results the three DRTV short form texts are easily understood by children between the ages of 8 and 13 .

Because DRTV short form spots exhibit a very recognizable style of delivery, we decided to carry out an extensive analysis of different prosodic features in order to establish their contribution to the persuasiveness of these advertisements (RQ3). 
The delivery of information in all three DRTV short form spots is highly marked in terms of tonality, tonicity and pitch movements. The texts are not only divided into a large number of short IPs, but the majority of them also contain two pitch prominent syllables: the head and the nucleus. It has already been established that some words, phrases and even clauses are regularly repeated in the three DRTV texts. In addition, these repeated structures are systematically delivered with the nucleus located on the same content word, thus violating the basic principle of tonicity that the nucleus should occur on new information.

The analysis of pitch movements used in the three DRTV short form spots showed that the prevailing pitch movement consists of either a high falling tone or in combination with a high level head. This is not surprising since the high falling tones indicate not only the default syntactic structure (statement, imperative, exclamation) but also a high degree of involvement and enthusiasm expressed by the speaker over the advertised products, as well as over their features which are so unique that they deserve to be presented as new information almost every time they occur in the text. A marked version of this tune consists of a rising head and a high fall which in statements usually implies protest, whereas in imperatives it is often used as a suggested course of action.

In summary, the findings of the structural and the linguistic analyses of the three DRTV short form spots indicate that these broadcast advertisements exhibit similar patterns of verbal and non-verbal persuasive communication. Whether these patterns really convince viewers and make them purchase the products remains to be researched. Furthermore, an analysis of consumer response related to different linguistic features of DRTV short form spots would be equally interesting and could probably be useful to producers of infomercials or their shorter forms.

\section{Conclusion}

The paper presents a detailed analysis of verbal and non-verbal persuasive communication in three DRTV short form spots. The findings indicate that DRTV short form spots (1) use verbal and non-verbal communication strategies to meet the requirements of AIDA mode; (2) exhibit lexically and syntactically less complex language which can be easily processed by any viewer; and (3) intensify the spoken delivery through highly marked intonation.

We suggest that further research should concentrate on response of potential consumers regarding the verbal and non-verbal persuasive strategies used in DRTV short form spots.

\section{References}

Areni, Charles S., and John R. Sparks. 2005. “Language Power and Persuasion.” Psychology \& Marketing 22(6):507-25. doi:10.1002/mar.20071.

Averbeck, Joshua M., and Claude Miller. 2014. "Expanding language Expectancy Theory: The Suasory Effects of Lexical Complexity and Syntactic Complexity on Effective Message Design." Communication Studies 65 (1): 72-95. doi:10.1080/10510974.2013.775955.

Brazil, David. 1997. The Communicative Value of Intonation in English. Cambridge: Cambridge University Press.

Burgoon, Michael, and Gerald R. Miller. 1985. “An expectancy interpretation of language and persuasion.” In The social and psychological contexts of language, edited by Howard Giles and Robert N. St. Clair, 199-229. London: Lawrence Erlbaum Associates.

Chattopadhyay, Amitava, Darren W. Dahl, Robin J. B. Ritchie, and Kimary N. Shahin. 2003. "Hearing 
Voices: The Impact of Announcer Speech Characteristics on Consumer Response to Broadcast

Advertising." Journal of Consumer Psychology 13 (3): 198-204. doi:10.1207/S15327663JCP1303_02.

Cobb, Tom. n.d. Web Vocabprofile. Accessed October 15, 2015. http://www.lextutor.ca/vp/eng/.

Communication Theory. n.d. "AIDA Model." Accessed October 15, 2015. http://communicationtheory.org/ aida-model/.

Craig, Traci Y., and Kevin L. Blankenship. 2011. "Language and Persuasion: Linguistic Extremity Influences Message Processing and Behavioural Intentions." Journal of Language and Social Psychology 30 (3): 290 310. doi:10.1177/0261927X11407167.

Cruttenden, Alan. 2014. Gimson's Pronunciation of English. London: Routledge.

Insko, Chester A. 1965. "Verbal Reinforcement of Attitude." Journal of Personality and Social Psychology 2: 621-23. doi:10.1037/h0022485.

HawthorneDirect. n.d. "Direct Response TV (DRTV) and Infomercial Marketing." Accessed October 15, 2015. http://www.hawthornedirect.com/drtv_101/Short-Form-Spots.htm.

Heatley, A., Paul I. S. Nation, and Averil Coxhead. 2002. RANGE and FREQUENCY Programs. http://www. victoria.ac.nz/lals/staff/paul-nation.aspx.

Highstreet TV. 2011 “Easy Feet.” YouTube Video, 1:51. October 12. https://www.youtube.com/ watch?feature=player_embedded\&v=SIBMS_KT8XI.

Highstreet TV. 2013. "Eggies." YouTube Video, 1:17. February 15. https://www.youtube.com/ watch?feature=player_embedded $\& v=1 \mathrm{Gas} 0 \mathrm{p} 7 \mathrm{ksYk} \#$ !.

Highstreet TV. 2013. "XHose.” YouTube Video, 1:58. January 29. https://www.youtube.com/

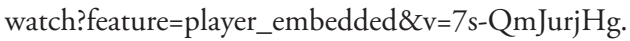

Ilc, Gašper, and Andrej Stopar. 2015. "Validating the Slovenian National Alignment to CEFR: The Case of the B2 Reading Comprehension Examination in English.” Language Testing 34 (2): 443-62. doi:10.1177/0265532214562098.

Lakoff, Robin. 1975. Language and Woman's Place. New York: Harper \& Row.

McNamara, Danielle S., Max M. Louwerse, Zhiqiang Cai, and Arthur C. Graesser. 2005. Coh-Metrix version 1.4. January 1. Accessed October 15, 2015. https://cohmetrix.memphis.edu.

McNamara, Danielle S., Arthur C. Graesser, and Zhiqiang Cai. 2014. Automated Evaluation of Text and Discourse with Coh-Metrix. New York: Cambridge University Press.

O’Barr, William M. 1982. Linguistic Evidence. Language, Power, and Strategy in the Courtroom. New York: Academic Press.

O'Connor, Joseph Desmond, and Gordon Frederic Arnold. 1973. Intonation of Colloquial English. Second Edition. London: Longman.

Pett, Richard E., and John Cacioppo. 1986. Communication and Persudsion: Central and Peripheral Routes to Attitude Change. New York: Springer.

Quirk, Randolph C., Sidney Greenbaum, Geoffrey Leech, and Jan Svartvik. 1987. A Comprehensive Grammar of the English Language. Longman.

Sparks, John R. and Charles S. Areni. 2002. "The Effects of Sales Presentation Quality and Initial Perceptions on Persuasion: A Multiple Role Perspective." Journal of Business Research 55 (6): 517-28. doi:10.1016/ S0148-2963(00)00173-9.

Tannen, Deborah. 2007. Talking Voices: Repetition, Dialogue, and Imagery in Conversational Discourse. 2nd Edition. Cambridge: Cambridge University Press. 
Wells, John Christopher. 2006. English Intonation. Cambridge: Cambridge University Press.

Wiener, Hillary J. D., and Tanya L. Chartrand. 2014. “The Effect of Voice Quality on Ad Efficacy.” Psychology and Marketing 31 (7): 509-17. doi:10.1002/mar.20712. 


\section{Appendix 1}

\section{Transcription of the three DRTV short form spots.}

\section{Legend:}

XXXX: black and white film

CAPITAL LETTERS: on-screen written text

\section{EGGIES}

Messy shells, broken whites, dirty hands.

Well, not any more.

\section{EGGIES BOILED EGGS WITHOUT THE SHELL!}

Introducing Eggies from New Innovations: the fast, fun, easy way to cook hard or soft boiled eggs without the shell.

\section{JUST CRACK \& POUR}

\section{TWIST OPEN}

Just crack and pour in your egg, boil it right on your hob, then twist open for a perfect-looking boiled egg.

COOKS LIKE REAL SHELL!

Look inside.

\section{EASILY SLIDES OUT!}

Eggies cook your eggs just like a real shell.

And the egg slides right out when you're done.

And here's something really handy.

\section{COOKS FLAT!}

\section{DECORATE}

Because Eggies cook flat on the bottom, they're easy to decorate.

\section{WITHOUT A SINGLE SHELL!}

Now you can enjoy delicious hard or soft boiled eggs without peeling a single shell.

FAST \& FRESH EGG SANDWICHES SLICED FOR SALADS!

Fast and fresh egg sandwiches or simply slice an egg over a scrumptious salad.

\section{TASTY TREAT KIDS LOVE}

Eggies help make a tasty treat the kids love to eat.

\section{CHOLESTEROL-FREE WHITES}

You can even cook your egg whites for a cholesterol-free alternative.

Look.

Peeling just one egg the regular way can be messy and take time.

QUICK, EASY\& MESS-FREE

But you can twist open Eggies eggs quick, easy and mess-free.

\section{ADD SEASONING BEFORE BOIL}

And because you cook without a shell, you can add seasoning 


\section{ADD INGREDIENTS BEFORE BOIL}

and ingredients before you boil.

Watch again.

\section{CRACK COOK TWIST}

Just crack, cook and twist.

With Eggies unique design to enjoy delicious hard or soft boiled eggs just like this.

\section{DISHWASHER SAFE}

And it's dishwasher-safe.

Save time in the kitchen and enjoy hard or soft boiled eggs for breakfast, lunch or dinner the Eggies way.

Got an egg?

Get an Eggies!

\section{EASY FEET}

How do you clean your feet?

You bend, stretch and you can't reach?

Keeping your tired feet looking and smelling great can be such a chore.

But not anymore.

\section{EASY FEET NEW INNOVATIONS}

Introducing Easy Feet from New Innovations.

The easy and convenient way to clean, massage and exfoliate your feet from heel to toe.

It's your very own foot spa to use in your shower or bath so you can treat yourself to a foot massage every day.

OVER 1000 BRISTLES CLEANS TOP

Easy Feet features over 1000 softly rejuvenating bristles that gently massage and clean the top

\section{AND BOTTOM}

of your feet, the toes and the bottom of your feet.

\section{BUILT IN PUMICE STONE}

It even has a built-in pumice stone for rough, dry heels. So now you can make ugly, dry skin and rough tired feet a thing of the past.

(Testimonial 1: "Easy Feet makes me feel a lot more confident when wearing my strappy shoes.")

$$
\text { MASSAGES ... EXFOLIATES! }
$$

Easy Feet's clever design not only cleans your feet, but massages, and gently exfoliates, too.

\section{ELIMINATES DIRT!}

Plus it eliminates dirt.

\section{CLEANS BETWEEN YOUR TOES}

And most importantly: Easy Feet cleans in between your toes.

(Testimonial 2: "It's great because you don't have to bend over and worry about slipping or falling. I can't believe how great it feels on my feet.") 


\section{SECURE TO ANY: SHOWER}

Just secure the easy to use Easy Feet to any smooth shower or bath surface with the built-in

BATH WALL

suction pads and turn your bath into a foot spa.

It's like a car wash for your feet.

ONE SIZE FITS ALL!

Easy Feet is one-size-fits-all.

GREAT FOR ALL THE FAMILY!

And it's perfect for people of all ages to help keep your feet clean, fresh and smelling great.

USE IN EVERY BATH \& SHOWER

Leave an Easy Feet in every bath and every shower.

\section{USE ANY TIME OF DAY!}

Don't get into bed and dirty your sheets when it only takes a minute to clean your feet.

NO MORE BENDING TO CLEAN YOUR FEET!

So stop doing that one-legged dance in the shower.

CLEAN ... MASSAGE ... EXFOLIATE!

Clean, massage and exfoliate with the safe and convenient Easy Feet.

\section{XHOSE}

The XHose!

The incredible expanding hose.

Watch this.

Turn the water on and the XHose automatically expands up to three times its original length. Turn the water off and as the water drains, the XHose automatically starts contracting until it's contracted back to a very small size.

AMAZING!

Amazing!

Ordinary fifty foot hoses can be heavy.

\section{INCREDIBLY LIGHT!}

The XHose is incredibly light.

50' WEIGHS ABOUT $1 \mathrm{lb}$ !

A fifty foot XHose weighs only about one pound.

And what a dream to handle!

\section{EXPAND UP TO 3 TIMES ITS LENGTH!}

Just turn the water on and the XHose quickly expands up to three times its length as you effortlessly guide it where you need to go. 
Imagine using a hose that is this light and this easy to handle.

\section{AUTOMATICALLY CONTRACTS!}

When you're finished, just drain the water that's in the hose and the XHose will automatically follow you back as it gets shorter and shorter until it contracts back to a compact size that stores quickly and easily.

UNBELIEVABLE!

Unbelievable!

\section{BUILT STRONG TO LAST LONG!}

The XHose is built strong to last long.

$$
\text { MADE FROM } 2 \text { HOSES! }
$$

EXPANDABLE INNER HOSE

It's actually made from two separate hoses: a tough expandable inner hose and a folded outer

$$
\text { SUPER STRONG WEBBING }
$$

hose made from durable super-strong webbing.

\section{WILL NEVER KINK!}

With the XHose you could never be stopped by kinks again.

That's because its patent pending design makes kinking virtually impossible.

\section{WIDE DIAMETER DEPENDENT ON WATER PRESSURE AVAILABLE} POWERFUL SPRAY

The XHose expands to a wide diameter that produces a powerful high flow spray for top jobs like cleaning second-floor windows.

In the past you had to struggle to get your tangled hose onto the reel.

The XHose contracts to an incredibly small size that stores easily.

\section{FOOT FITS IN A FLOWER POT!}

Believe it or not: a seventy-five foot XHose fits in a flower pot.

$$
\text { SO LIGHT! }
$$

SO EASY!

And because it's so light, watering your flowers and garden or washing your car has never been easier.

\section{RVS AND BOATS!}

Save space in RV's and on boats.

\section{AUTOMATICALLY EXPANDS!}

And like no other hose in the world, the XHose automatically expands up to three times its length in a matter of seconds.

\section{AUTOMATICALLY CONTRACTS!}

And just as quickly contracts back.

Get your very own XHose, the incredible expanding hose, today. 